\title{
Correction to: Evaluation of Two Optical Probes for Imaging the Integrin av $\beta 6$ - In Vitro and In Vivo in Tumor-Bearing Mice
}

Tanushree Ganguly, ${ }^{1}$ Sarah Y. Tang, ${ }^{1}$ Nadine Bauer, ${ }^{1}$ Julie L. Sutcliffe ${ }^{1,2,3}$

${ }^{1}$ Department of Internal Medicine, Division of Hematology \& Oncology, University of California, Davis, CA, USA

${ }^{2}$ Department of Biomedical Engineering, University of California, Davis, CA, USA

${ }^{3}$ Center for Molecular and Genomic Imaging, University of California, Davis, CA, USA

Correction to: Mol Imaging Biol (2020)

https://doi.org/10.1007/s11307-019-01469-5

This article was updated to correct the axes in Figures 4e and 5d. 

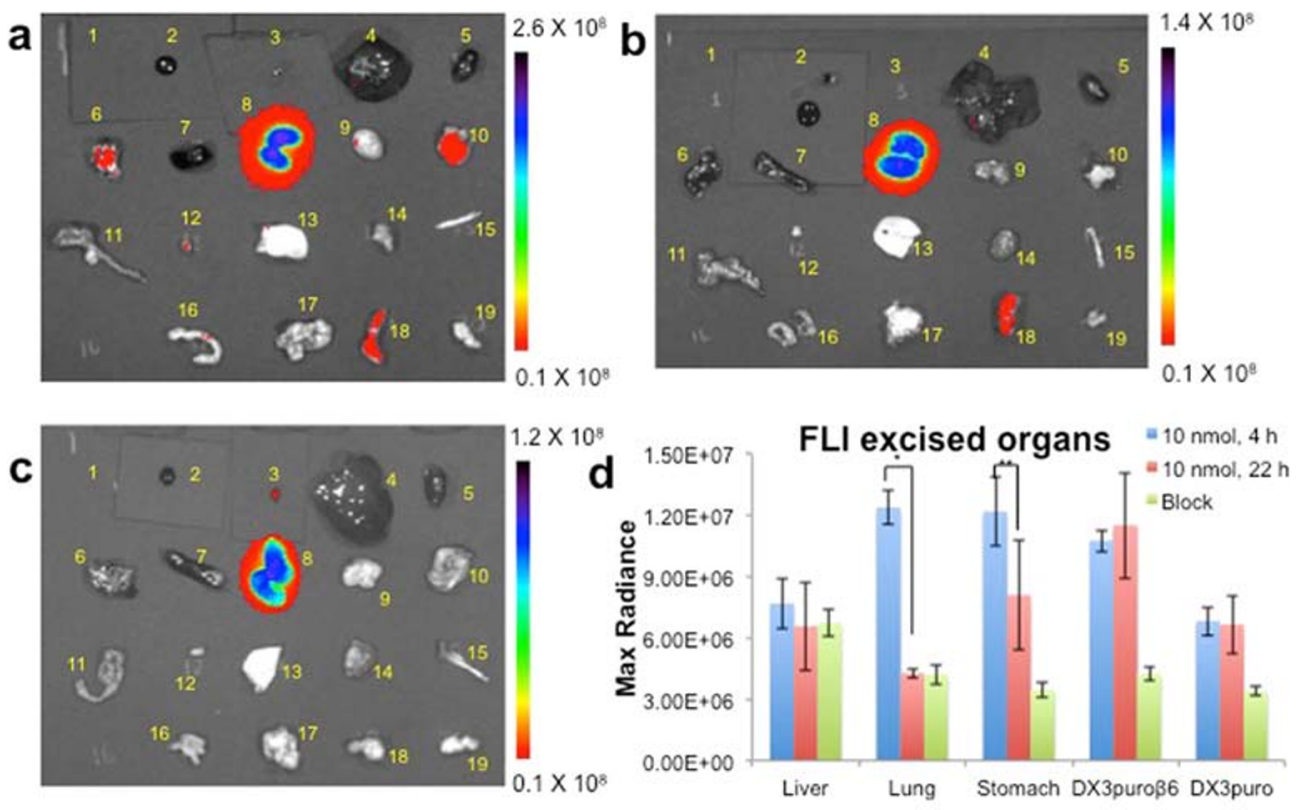

1. Urine, 2. Blood, 3. Gall Bladder, 4. Liver, 5. Heart, 6. Lung, 7. Spleen, 8. Kidneys, 9. Pancreas, 10. Stomach, 11. Small Intestine, 12. Bladder, 13. Skin (ear). 14. Muscle, 15. Bone, 16. Large Intestine, 17. Brain, 18. DX3puro $\beta_{6}$ 19. DX3puro.
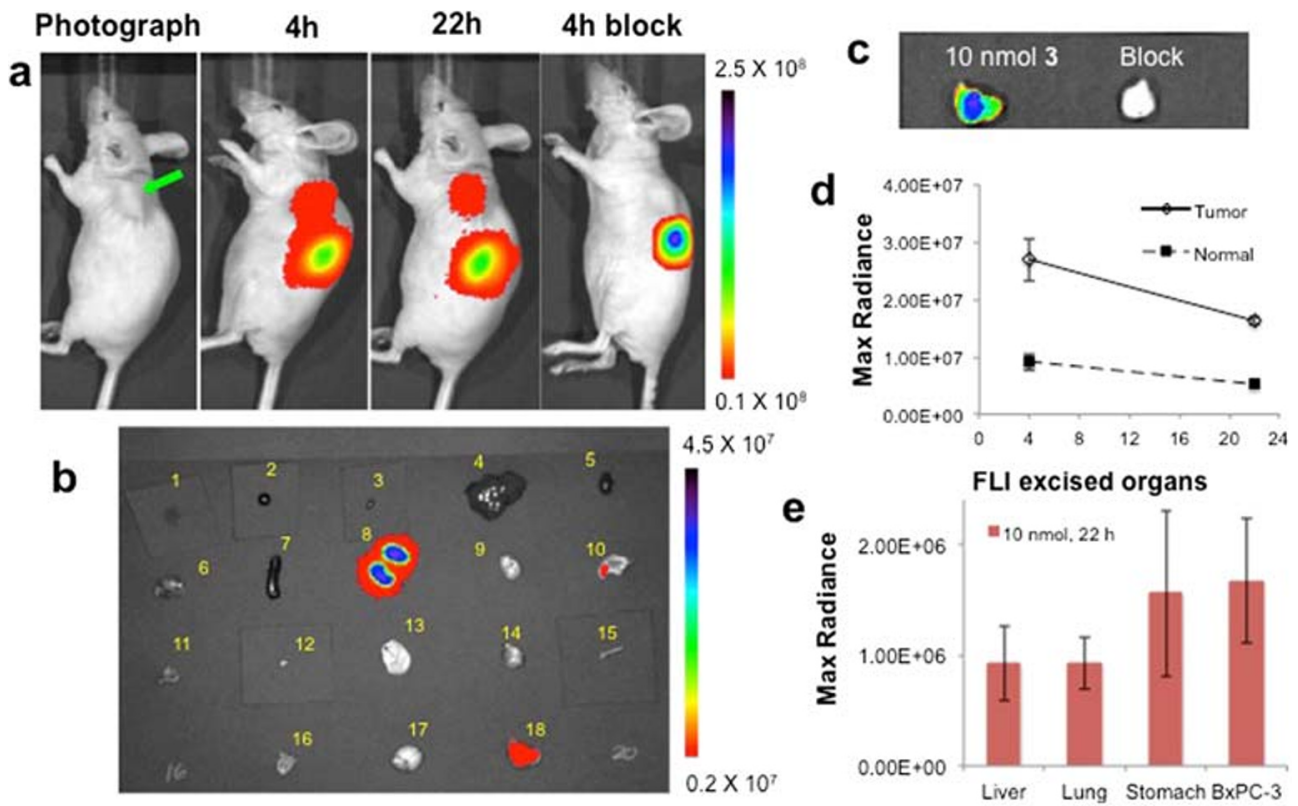

1. Urine, 2. Blood, 3. Gall Bladder, 4. Liver, 5. Heart, 6. Lung, 7. Spleen. 8. Kidneys, 9. Pancreas, 10. Stomach, 11. Small Intestine. 12. Bladder, 13. Skin (ear). 14. Muscle, 15. Bone, 16. Large Intestine, 17. Brain, 18. BxPC-3 Tumor. 